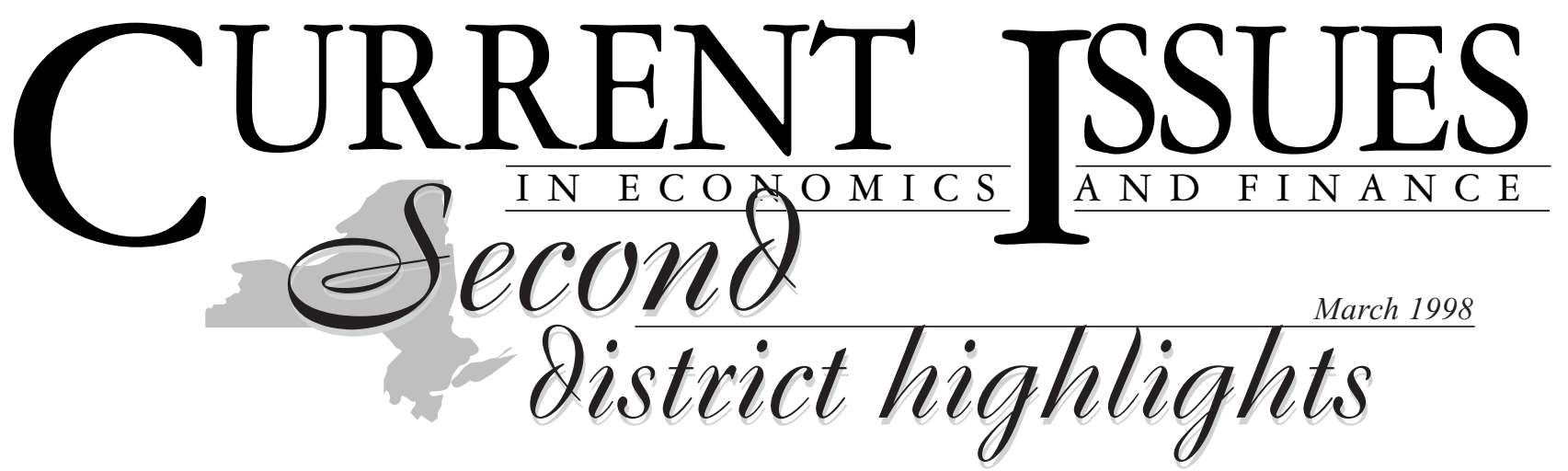

\title{
New York-New Jersey Job Recovery Expected to Continue in 1998
}

In 1997, employment growth in the New York-New Jersey region accelerated to 1.7 percent, its highest annual rate since 1988. Relatively strong job growth in the New York City metropolitan area and a doubling of job growth in New Jersey helped the region to continue its pattern of gradual but steady recovery. Nineteen ninety-eight, however, is likely to be a year of slightly slower growth - owing largely to the effects of a projected slowing of growth in the national economy-yet the region's recovery pattern should remain unbroken.

In this edition of Second District Highlights, we recap the employment performance of the New York-New Jersey region in 1997 and present our forecast for the region's job growth in 1998. We identify the key industry developments that will shape regional employment trends and compare the projected job growth performance of New York State, New York City, and New Jersey. In a departure from previous regional analyses, we also consider two international factors that could affect employment trends: the turmoil in the Asian markets and the recent drafting of a global agreement liberalizing trade in financial services. We expect that any direct negative impact from the Asian market developments will be fairly minor, while the financial services agreement should improve prospects for regional employment.

\section{Job Growth Review}

Strong national economic activity, the continuing boom on Wall Street, and an easing of downsizings in the manufacturing and government sectors contributed to New York and New Jersey's employment growth last year. With 195,000 new jobs created, the region enjoyed a 1.7 percent growth rate (Table 1). The trade and services sectors continued to be the mainstays of growth, accounting for more than 173,000 new jobs; the trade sector's growth rate was double its 1996 rate while the services sector saw robust 3.7 per- cent growth. Also boosting employment growth were gains in the construction sector, the FIRE (finance, insurance, and real estate) sector, and the transportation, communications, and public utilities sector. Declines in the manufacturing and government sectors were smaller than in 1996.

Within the region, the steady recovery trend was evident on most fronts. New Jersey employment rose by more than 85,000 jobs, or 2.4 percent - more than double the growth rate for 1996. The state's average level of employment, at 3.7 million workers, broke an eight-year record. Virtually all of New Jersey's job growth occurred in the private sector; public sector employment was essentially flat.

In New York State, employment growth of 1.4 percent generated approximately 110,000 new jobs. Within the

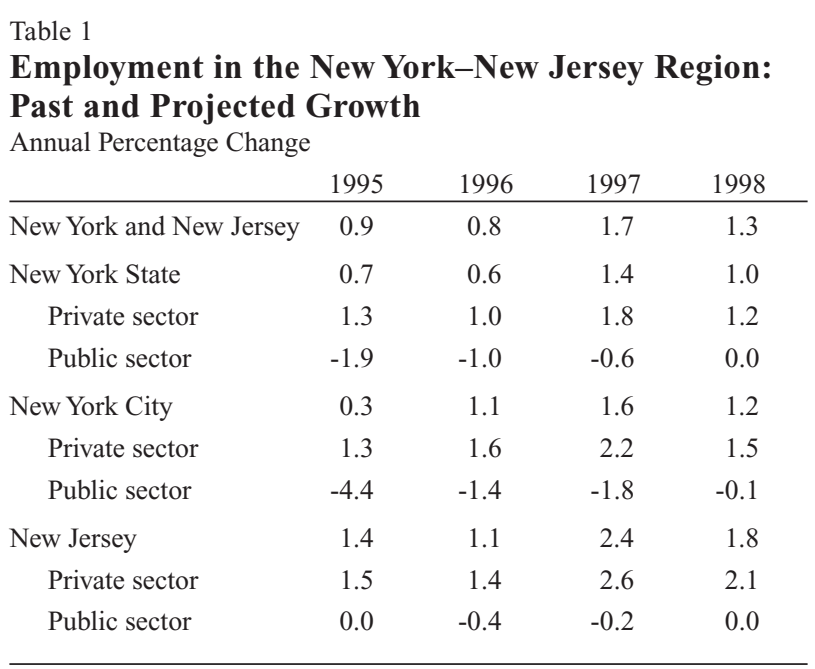

Sources: U.S. Department of Labor; Federal Reserve Bank of New York projections. Note: The 1998 figures are projections. 
state, New York City produced 53,000 new jobs and saw its employment expand by 1.6 percent. Private sector job growth in the state and the city was considerably stronger than overall job growth because public sector downsizings again exerted a drag on job growth.

The New York City metropolitan area continued its solid performance from $1996 .{ }^{1}$ Jobs in the area rose by 1.6 percent — outperforming employment in the rest of New York State, which expanded by 0.9 percent. The 0.9 percent expansion, however, marked a sizable improvement from the rest of the state's 1996 growth rate of 0.1 percent.

\section{Job Growth Preview}

An anticipated slowing of growth in the U.S. economy will help put a modest brake on the region's job growth. ${ }^{2} \mathrm{We}$ project employment to rise, but by 1.3 percent, or roughly 149,000 jobs (Table 1). Nevertheless, this growth rate will exceed the rates set in 1996 and 1995 and continue the region's pattern of gradual but steady recovery. The broad contours of growth are expected to mirror those from 1997, with trade and services - particularly business and consumer services - maintaining the lead. Growth in the FIRE sector should match its 1997 rate, which, owing to gains in New Jersey, had reversed a weak trend from 1996 and 1995. The pace of employment decline in the manufacturing sector should pick up slightly with the slowing of growth in national activity and the continued relocation of jobs to other regions. The government sector is projected to remain flat, and growth in transportation, communications, and public utilities should slow, although this sector is still expected to generate about 5,000 new jobs.

Within the region, we forecast that New Jersey will add 67,000 new jobs and register growth of 1.8 percenta decline from the 1997 rate. New Jersey's rate, however, will exceed the 1.0 percent growth we project for New York State, but by less than it did last year. Approximately 81,000 new jobs should be created in New York. The gap between the 1997 private sector growth rates for New York and New Jersey-which had widened during 1996-will remain. Job levels in New York State's public sector should stabilize: no government losses are anticipated overall at the state level.

Overall job growth in New York City is projected to reach 1.2 percent, a fall from the 1997 rate. The city can expect to gain roughly 42,000 new jobs- $-10,000$ fewer jobs than last year.

The Asian Markets Factor. The turmoil in the Asian markets and the resulting sharp depreciation of several key Asian currencies have led many economists to pre- dict an influx of Asian manufactured goods to the United States and a drop-off in U.S. manufactured exports to Asia. Such developments could compound the dampening effects of the U.S. dollar's 1997 appreciation on the demand for U.S. manufactured goods.

How will industry in New York and New Jersey - and hence the region's employment performance-be affected? Fortunately, the New York and New Jersey economies are dominated by production in the services sector, making the states less reliant than the nation as a whole on exports of manufactured goods. For example, New York's and New Jersey's manufactured exports to the world markets represent, respectively, just 6 percent and 5 percent of gross production-well below the national average of 8 percent. ${ }^{3}$ In addition, if we break down the states' exports by market, we see that just 19 percent of New York's, and 14 percent of New Jersey's, manufactured exports were destined for Asian markets last year-as compared, for example, with roughly 55 percent of exports from California, Washington, or Oregon (Table 2). Consequently, the region's sensitivity to a slowdown in Asian demand for U.S. manufactured exports - and any vulnerability of job growth - should be blunted by the relatively low volume of those exports to Asian countries.

However, the Asian markets' effect on the region's exports to Europe and Canada may bear watching. Europe and Canada are the region's main export marketsroughly half of New York and New Jersey's manufactured goods are exported there (Table 2). With the depreciation of Asian currencies, Asian firms may be able to step up their exports to Europe and Canada, gaining market share at the expense of U.S. exporters, including those in New York and New Jersey.

Foreign Trade in Financial Services. Regional job performance in 1998 and beyond could also be affected by the opening of trade in financial services to a wider global marketplace. Historically, trade barriers in many countries have curtailed U.S. financial institutions' operations in the world markets. ${ }^{4}$ Until recently, little progress had been made in liberalizing trade in financial services because attention was focused almost wholly on trade in goods. However, that attention has since shifted as the global economy has become increasingly services-oriented-as evidenced by the rise in demand for such service exports as tourism, management consulting, and accounting. Financial services, too, are expected to experience heightened international demand. The incentives for liberalized trade coalesced in December 1997: the World Trade Organization (WTO) drafted an agreement that loosens restrictions on trade in financial services, broadening inter- 
Table 2

\section{Patterns of Merchandise Exports}

\begin{tabular}{lccccc} 
& $\begin{array}{c}\text { Total Goods Exported } \\
\text { (Billions of Dollars) }\end{array}$ & $\begin{array}{c}\text { Exports to Asia } \\
\text { (Billions of Dollars) }\end{array}$ & $\begin{array}{c}\text { Percent Exported } \\
\text { to Asia }\end{array}$ & $\begin{array}{c}\text { Exports to Europe and Canada } \\
\text { (Billions of Dollars) }\end{array}$ & $\begin{array}{c}\text { Percent Exported } \\
\text { to Europe and Canada }\end{array}$ \\
\hline New York & 38.7 & 7.4 & 19.2 & 22.2 & 57.3 \\
New Jersey & 14.9 & 2.1 & 14.1 & 7.0 & 47.1 \\
West Coast & & & & & 29.8 \\
$\quad$ California & 104.5 & 57.4 & 54.9 & 7.5 & 28.5 \\
$\quad$ Washington & 29.4 & 16.1 & 54.9 & 2.8 & 25.5 \\
$\quad$ Oregon & 9.8 & 5.2 & 53.1 & & 28.5 \\
\hline
\end{tabular}

Source: Authors' calculations, based on data from the Massachusetts Institute of Social and Economic Research developed under a contract with the U.S. Bureau of the Census.

Note: Figures are for 1996 - the last year for which data are available.

national opportunities for U.S. companies and other firms that offer these services. The seventy or so participating countries are expected to ratify the agreement by January 1999. However, because some countries have chosen to open their markets well ahead of agreement schedules and ratifications, the expansion of U.S. financial services firms abroad has already begun.

With liberalized trade in financial services under way, the employment outlook is promising for the service economies of New York and New Jersey. The New York City metropolitan area in particular stands to gain: a world capital of finance, the metropolitan area is also a dominant producer of supporting business services such as legal counsel, accounting, consulting, and advertising - many of which are already exported. Although the effects of the WTO agreement will become clear only over time, U.S. firms in the metro area's FIRE sector are very likely to improve their business opportunities (Rosen and Murray 1997). As these firms expand abroad through mergers, acquisitions, and the establishment of branches, the underlying administrative and managerial staff in the New York-New Jersey region should expand accordingly. Demand for supporting business services should also rise, further boosting employment in the region.

- James Orr, Rae D. Rosen, and Mike De Mott

\begin{abstract}
Notes
1. We define the metropolitan area as New York City, Long Island, and Rockland, Putnam, and Westchester Counties; it accounted for 60 percent of New York State employment in 1997.

2. The average projection for real GDP growth is 2.6 percent, compared with 3.8 percent for 1997 (Blue Chip Consensus Forecast 1998).

3. Gross production figures are as of 1994 - the last year for which data are available.

4. For example, in some countries, U.S. brokerage firms, insurance companies, and banks are prohibited from offering financial services or are severely limited in the types of financial products they can sell; U.S. mutual funds and management companies are prohibited entirely from operating in some countries.
\end{abstract}

\footnotetext{
REFERENCES

Blue Chip Consensus Forecast. 1998. Vol. 23, no. 2, February 10.

Rosen, Rae D., and Reagan Murray. 1997. "Opening Doors: Access to the Global Market for Financial Services." In Margaret E. Crahan and Alberto Vourvoulias-Bush, eds., The City and the World: New York's Global Future, 39-50. New York: Council on Foreign Relations.
}

The views expressed in this article are those of the authors and do not necessarily reflect the position of the Federal Reserve Bank of New York or the Federal Reserve System.

Second District Highlights, a supplement to Current Issues in Economics and Finance, is published by the Research and Market Analysis Group of the Federal Reserve Bank of New York. Dorothy Meadow Sobol is the editor. 


\section{Economic Trends in the Second District}

\section{Payroll Employment}

Index: $1990=100$ (seasonally adjusted)

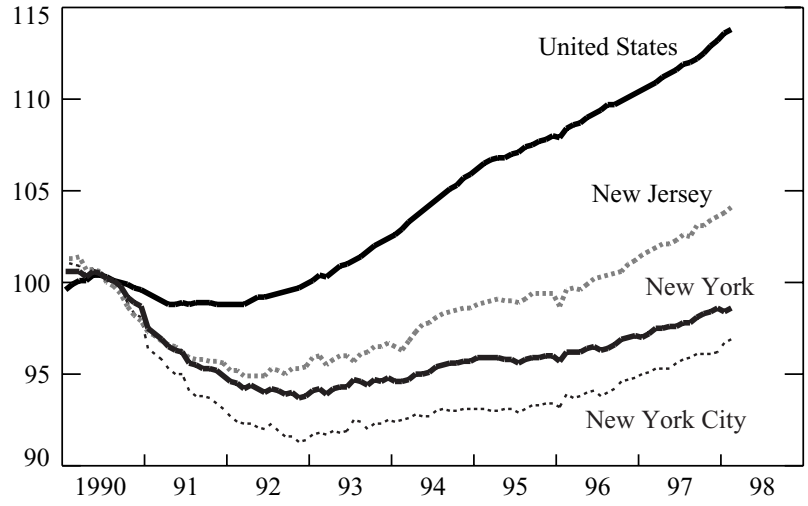

Payroll Employment in Selected Sectors

New York and New Jersey Combined

Index: $1990=100$ (seasonally adjusted)

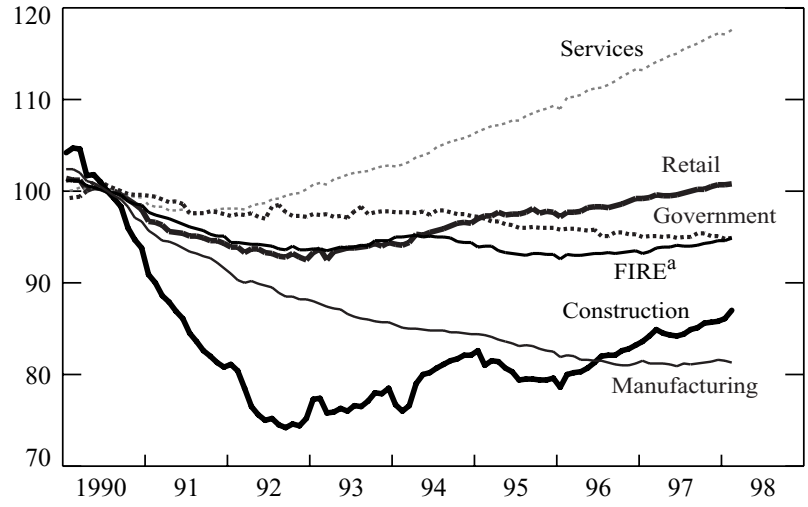

Regional and National Inflation

Twelve-Month Percentage Change in Consumer Price Index

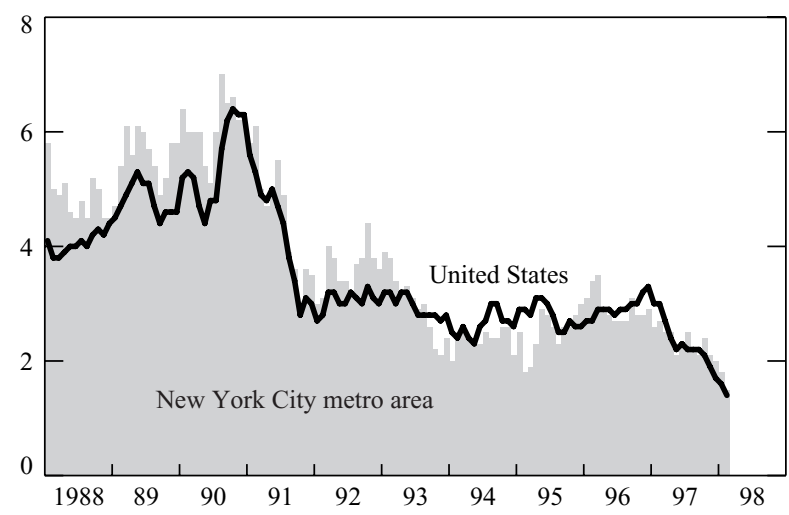

Sources: New York, New Jersey, and Connecticut Departments of Labor; U.S. Department of Labor, Bureau of Labor Statistics; U.S. Department of Commerce, Bureau of the Census; Federal Reserve Bank of New York.

${ }^{\mathrm{a}} \mathrm{FIRE}=$ finance, insurance, and real estate.

${ }^{\mathrm{b}}$ Upstate N.Y. comprises the four metropolitan areas listed as well as Binghamton, Elmira, Glens Falls, Jamestown, and Utica-Rome.
Unemployment Rates

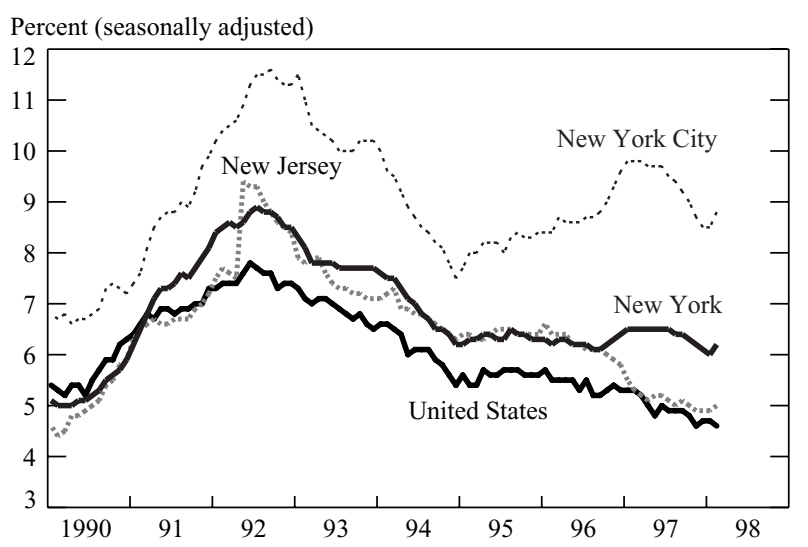

Job Growth in the Nation and Selected Metropolitan Areas December-February 1997 to December-February 1998

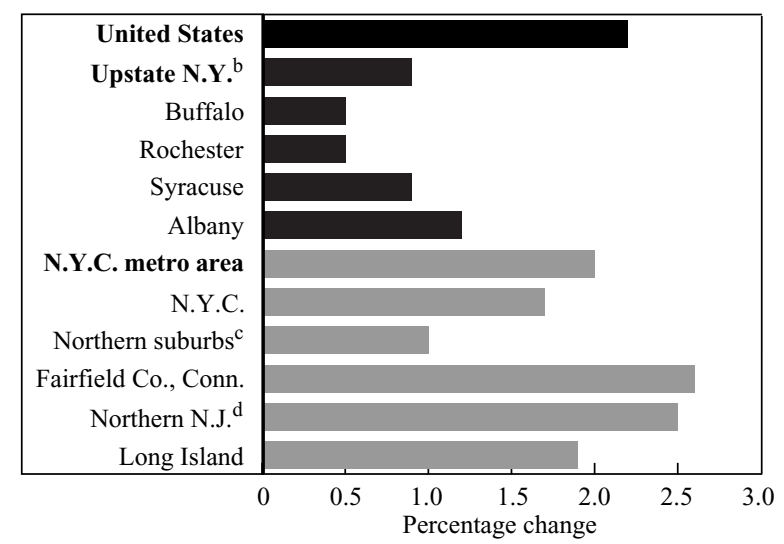

Housing Permits in New York and New Jersey Combined Twelve-Month Moving Average, Annual Rate

Thousands

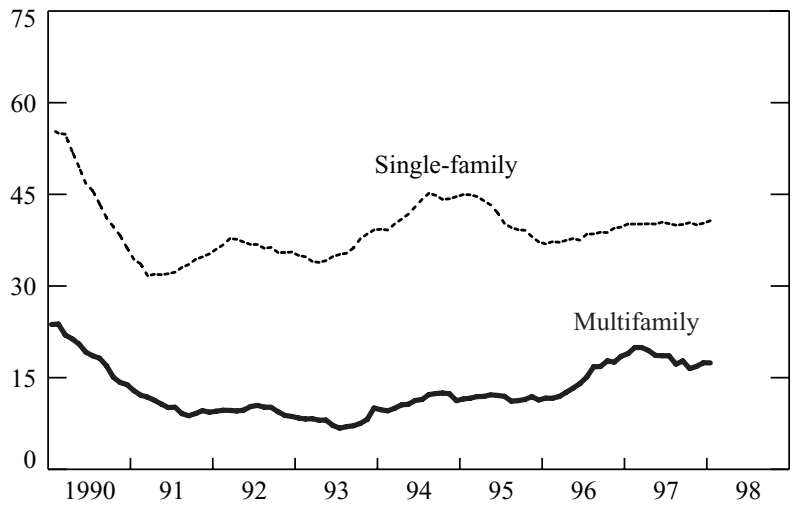

${ }^{\mathrm{c}}$ The northern suburbs of N.Y.C. comprise Dutchess, Orange, Putnam, Rockland, and Westchester Counties, N.Y., and Pike County, Pa.

${ }^{\mathrm{d}}$ Northern N.J. comprises Bergen, Essex, Hudson, Hunterdon, Mercer, Middlesex, Monmouth, Morris, Ocean, Passaic, Somerset, Sussex, Union, and Warren Counties. 